\title{
Seasonal variation of the protozooplanktonic community in a tropical oligotrophic environment (Ilha Solteira reservoir, Brazil)
}

\author{
Mansano, AS. ${ }^{a *}$, Hisatugo, KF. ${ }^{a}$, Leite, MA. ${ }^{b}$, Luzia, AP. ${ }^{a}$ and Regali-Seleghim, MH. ${ }^{a}$ \\ ${ }^{a}$ Departamento de Ecologia e Biologia Evolutiva, Universidade Federal de São Carlos - UFSCar, \\ Rod. Washington Luis, Km 235, CEP 13564-905, São Carlos, SP, Brazil \\ ${ }^{b}$ Departamento de Fitossanidade, Engenharia Rural e Solos, Faculdade de Engenharia de Ilha Solteira, \\ Universidade Estadual Paulista - UNESP, Rua Monção, 226, CEP 15385-000, Ilha Solteira, SP, Brazil \\ *e-mail: laine_mansano@yahoo.com.br
}

Received December 5, 2011 - Accepted June 16, 2012 - Distributed May 31, 2013

(With 5 figures)

\begin{abstract}
The seasonal variation of the protozooplanktonic community (ciliates and testate amoebae) was studied in a tropical oligotrophic reservoir in Brazil, which was under the influence of two contrasting climatic seasons (rainy/warm and dry/cold). The aim of this study was to evaluate the effect of these climatic changes on physical, chemical and biological variables in the dynamic of this community. The highest mean density of total protozoans occurred in the rainy/warm season $\left(5683.2\right.$ ind $\left.\mathrm{L}^{-1}\right)$, while the lowest was in the dry/cold $\left(2016.0\right.$ ind $\left.\mathrm{L}^{-1}\right)$. Considering the seasonal variations, the protozoan groups that are truly planktonic, such as the oligotrichs (Spirotrichea), predominated in the dry season, whereas during the rainy season, due to the material input and resuspension of sediment, sessile protozoans of the Peritrichia group were the most important ones. The dominant protozoans were Urotricha globosa, Cothurnia annulata, Pseudodifflugia sp. and Halteria grandinella. The highest densities of $H$. grandinella were associated with more oxygenated and transparent water conditions, while the highest densities of $C$. annulata occurred in sites with high turbidity, $\mathrm{pH}$ and trophic state index (TSI). The study demonstrated that density and composition of protozooplanktonic species and groups of the reservoir suffered seasonal variation due to the environmental variables (mainly temperature, turbidity, water transparency, dissolved oxygen and TSI) and the biological variables (e.g. morphological characteristics, eating habits and escape strategies from predation of the species).
\end{abstract}

Keywords: protozoans, freshwater, ciliates, testate amoebae.

\section{Variação sazonal da comunidade protozooplanctônica em um ambiente oligotrófico tropical (reservatório de Ilha Solteira, Brasil)}

\section{Resumo}

A variação sazonal da comunidade protozooplanctônica (ciliados e amebas testáceas) foi estudada em um reservatório oligotrófico tropical no Brasil, que estava sob a influência de dois períodos climáticos contrastantes (chuvoso/quente e seco/frio). O objetivo deste estudo foi avaliar os efeitos destas mudanças climáticas sobre as variáveis físicas, químicas e biológicas na dinâmica desta comunidade. A maior densidade média de protozoários total ocorreu no período chuvoso e quente $\left(5683,2\right.$ ind $\left.\mathrm{L}^{-1}\right)$, enquanto a menor foi no período seco e frio $\left(2016,0\right.$ ind $\left.\mathrm{L}^{-1}\right)$. Considerando-se as variações sazonais, os grupos de protozoários que são verdadeiramente planctônicos, como os oligotrichs (Spirotrichea), predominaram no período seco, enquanto que, no período chuvoso, em razão da entrada de material e da ressuspensão do sedimento, os protozoários sésseis do grupo Peritrichia foram os mais importantes. Os protozoários dominantes foram Urotricha globosa, Cothurnia annulata, Pseudodifflugia sp. e Halteria grandinella. As maiores densidades de H. grandinella foram associadas com condições de águas mais oxigenadas e transparentes, enquanto que as maiores densidades de $C$. annulata ocorreram em locais com alta turbidez, pH e índice de estado trófico (IET). O estudo demonstrou que a densidade e a composição de espécies, e os grupos protozooplanctônicos do reservatório sofreram variação sazonal por causa das variáveis ambientais - principalmente temperatura, além de turbidez, transparência da água, oxigênio dissolvido e IET - e das variáveis biológicas, como, por exemplos, características morfológicas, hábitos alimentares e estratégias de escape à predação das espécies.

Palavras-chave: protozoários, águas doces, ciliados, amebas testáceas. 


\section{Introduction}

Since limnologists started to include protozooplankton in their studies (e.g. Pace and Orcutt, 1981), protozoans are seen as a significant portion of the microzooplankton community (Beaver and Crisman, 1990) and an important link in the food chain, performing a key role in energy flow and acting as important mineralizing agents of limiting essential nutrients such as phosphorus and nitrogen (Azam et al., 1983). More recently, studies have shown their importance as consumers and controllers of the bacterial community, causing direct impacts on their production, biomass, structure, morphology, physiology, taxonomy and diversity (e.g. Pernthaler, 2005; Corno et al., 2008; Bell et al., 2010). Furthermore, due to the fact that they respond to low organic pollution levels and other physical, chemical and biotic alterations, they may be used as indicators of ecological changes in aquatic ecosystems (Foissner, 1988; Paerl et al., 2003).

The trophic state of aquatic environments is essential in determining patterns of spatial and temporal variation of planktonic protozoans (Velho et al., 2005). It is known, for example, that recycling of carbon and nutrients through the microbial food chain is very important in oligotrophic environments, where trophic interactions are tightly coupled (Tremaine and Mills, 1991). Despite the potential importance of protozoans in oligotrophic systems, they have received less attention than in eutrophic and mesotrophic ones (Quevedo et al., 2003). According to Laybourn-Parry and Walton (1998), they are neglected because the techniques are more difficult to apply in this kind of water, where the organisms are scarce and often stressed.

Studies on protozoan seasonal variations, mainly in oligotrophic environments, are essential to: 1) interpret the factors that mediate the patterns of abundance and species succession and 2) provide data for incorporation in models that describe the dynamic in the plankton, especially in tropical regions, where data about these organisms are scarce. Thus, in this study we investigated possible seasonal patterns in protozooplankton (ciliates and testate amoebae) in a Brazilian oligotrophic aquatic environment situated in a tropical region (Ilha Solteira reservoir). The main objective was to investigate possible influences of the physical, chemical and biological environmental characteristics over the distribution of the protozoans, in rainy/warm and dry/cold seasons that characterize the climate of the region where the reservoir is situated.

\section{Material and Methods}

\subsection{Study area and sampling}

The studied system was Ilha Solteira reservoir, which lies in the states of São Paulo, Mato Grosso do Sul, Goias and Minas Gerais and has as its main affluent rivers the Paranaiba and Grande. The length of the reservoir is about $70 \mathrm{~km}$, with a maximum volume of $210.6 \times 10^{8} \mathrm{~m}^{3}$ and a mean depth of $17 \mathrm{~m}$. The region has a tropical climate $-\mathrm{Aw}$ (Köppen's classification), which is characterized by a rainy summer and dry winter, with an annual mean temperature of $23.7^{\circ} \mathrm{C}$ and annual rainfall of $1,300 \mathrm{~mm}$.

Taking into consideration mainly the morphology of the system, six sampling points were selected along the reservoir (see Figure 1) where four samplings were conducted in 2007: January and March in the rainy/warm period and May and August in the dry/cold period. Water samples were collected from the surface of the sampling points, using a Van Dorn bottle (2 L) and were used for protozooplankton counts and limnological analyses. Samples filtered in a plankton net $(10 \mu \mathrm{m}$ pore diameter $)$ were used for protozooplankton qualitative analyses.

\subsection{Limnological analyses and trophic state index}

In the field, the water $\mathrm{pH}$, dissolved oxygen (DO) and temperature were measured using a multiparameter probe (YSI 6820). The water transparency was measured by the Secchi disk and the turbidity by a turbidimeter $(\mathrm{HACH}$ Model AN2100). After the water was sampled, the total phosphorus was determined according to Valderrama (1981), the total dissolved phosphorus as Golterman et al. (1978) and the biochemical oxygen demand $\left(\mathrm{BOD}_{5}\right)$ using the modified Winkler method (APHA, 1995). To determine the concentration of chlorophyll $a$, samples were filtered in $\mathrm{GF} / \mathrm{C}$ (Whatman ${ }^{\circledR}$ ) filter and the extraction was made with ethanol $80 \%$ heated to $75^{\circ} \mathrm{C}$ (Nusch, 1980).

The reservoir was classified in accordance with the trophic state index (TSI) from Carlson (1977) modified by Toledo et al. (1983) that uses water transparency, total phosphorus, total dissolved phosphorus and chlorophyll $a$ data.

\subsection{Analysis of protozooplankton (ciliates and testate amoebae)}

For protozoan identification, water samples were filtered using a plankton net $(10 \mu \mathrm{m})$ and stored in plastic flasks. In the laboratory, the protozoan were analyzed in vivo, within a maximum period of 6 hours after the sampling, using an optical microscope, based mainly on the work of Edmondson (1959), Foissner and Berger (1996), Foissner et al. (1999) and Lee et al. (1985). The identified ciliates were classified according to Lynn (2008) and the testate amoebae were classified according to the Systema Naturae 2000 (Brands, 1989-2005).

For protozoan counts, water samples $(400 \mathrm{~mL})$ were placed in snap-cap flasks and fixed in the field with mercuric chloride and stained with bromophenol blue at $0.04 \%$, according to Pace and Orcutt (1981). In the laboratory, the samples were left undisturbed for the sedimentation of organisms and particulate matter. The supernatant liquid was discarded and the remaining concentrated material was counted in Sedgwick-Rafter chambers in an optical microscope. Protozoan taxonomic features were also analyzed in counts from fixed samples.

\subsection{Statistical analyses}

The Student's t-test was used to observe possible differences between the climatic seasons (rainy and dry). The Pearson correlation test was performed to determine 


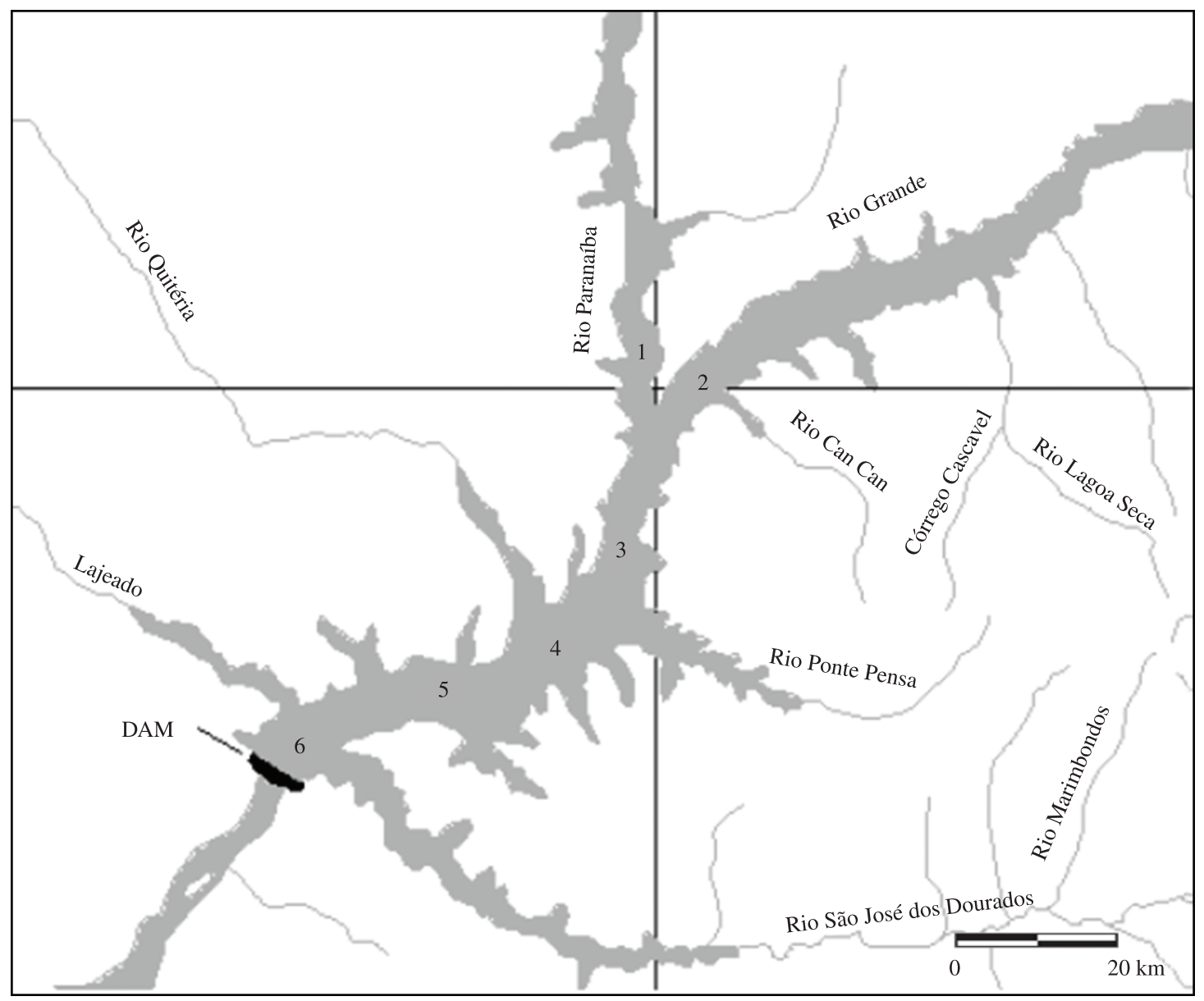

Figure 1. Localization of the sampling points in Ilha Solteira reservoir, Brazil.

the relationships among the different studied variables. The Principal Component Analysis (PCA) was used as a method of ordination of the correlations among physical, chemical and biological water variables. The Canonical Correspondence Analysis (CCA) was used to detect a pattern of variation in the species composition, and the main relationships among species and environmental variables. All the statistical analysis was performed using the XLSTAT Pro 2008 software.

\section{Results}

The trophic state index (TSI) calculated for the sampled points during the studied period $\left(\mathrm{TSI}_{\mathrm{P} 1}=26.4\right.$;SI $_{\mathrm{P} 2}=31.2$;

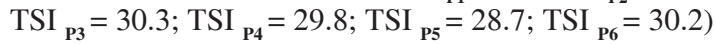
reveals that all of them were classified as oligotrophic. Student's t-tests showed that the physical, chemical and biological variables were significantly different between the rainy and dry seasons revealing a well-defined seasonal pattern. Thus, the general descriptive statistics of all variables analyzed in the reservoir for the two seasons are shown in Table 1. In Figure 2, a clear distinction between the sampled months can be observed from the principal component analysis (PCA), also defining a seasonal pattern with the rainy (January and March) and dry (May and August) periods. The rainy season was marked by higher values of temperature, turbidity, chlorophyll $a, \mathrm{pH}$ and trophic state index (TSI). The dry season (mainly in August) was marked by higher values of oxygen concentrations and water transparency. Points P5 and P6, in March, differed from all the others by having high concentrations of chlorophyll $a$.

Table 2 shows the relative proportions (\%) of the protozoan taxa identified in the reservoir and the mean values for their annual densities and for their densities in the rainy and dry seasons. The six dominant taxa that contributed with $71.2 \%$ of the total protozoan density in the reservoir were, respectively, Urotricha globosa, Cothurnia annulata, Pseudodifflugia sp., Halteria grandinella, Ctedoctema acanthocryptum and Vorticella aquadulcis-complex (see Figure 3 ). From the 31 protozoan taxa observed in the reservoir, 6 were testate amoebae and 25 were ciliates (see Table 2). The highest species richness was observed in January (24 taxa) and the lowest in August (15 taxa).

In terms of density, there was a predominance of bacterivorous/algivores, followed by bacterivorous protozoans in the system. The highest ciliate and testate amoebae densities occurred in the rainy/warm season (January and March) and the lowest in the dry/cold season (May and 
Table 1. Descriptive statistics of variables analyzed in Ilha Solteira reservoir in the dry season (January and March 2007) and in the dry season (May and August 2007).

\begin{tabular}{|c|c|c|c|c|c|c|c|c|}
\hline \multirow{2}{*}{ Variable } & \multicolumn{4}{|c|}{ Rainy season } & \multicolumn{4}{|c|}{ Dry season } \\
\hline & mean & $\min$ & $\max$ & SD & mean & $\min$ & $\max$ & SD \\
\hline Chlorophyll $a\left(\mu \mathrm{g} \mathrm{L}^{-1}\right)$ & 2.3 & 0.0 & 10.4 & 2.8 & 0.8 & 0.0 & 1.7 & 0.5 \\
\hline $\mathrm{pH}$ & 7.6 & 7.4 & 8.1 & 0.2 & 6.9 & 6.2 & 7.6 & 0.5 \\
\hline $\mathrm{DO}\left(\mathrm{mg} \mathrm{L}^{-1}\right)$ & 6.1 & 4.8 & 6.7 & 0.5 & 7.0 & 6.0 & 7.8 & 0.7 \\
\hline $\mathrm{BOD}\left(\mathrm{mg} \mathrm{L}^{-1}\right)$ & 0.6 & 0.2 & 1.0 & 0.3 & 0.3 & 0.0 & 0.6 & 0.2 \\
\hline Temperature $\left({ }^{\circ} \mathrm{C}\right)$ & 28.3 & 27.0 & 30.0 & 1.0 & 24.2 & 23.0 & 25.0 & 0.8 \\
\hline Transparency (m) & 1.2 & 0.5 & 1.7 & 0.4 & 5.0 & 2.5 & 7.5 & 1.7 \\
\hline Turbidity (NTU) & 17.8 & 7.2 & 35.3 & 7.3 & 2.5 & 0.8 & 5.5 & 1.7 \\
\hline Trophic state index & 36.9 & 21.6 & 43.7 & 6.3 & 26.8 & 13.3 & 35.8 & 6.2 \\
\hline Ciliate density (ind $\mathrm{L}^{-1}$ ) & 4795.2 & 2850.0 & 6919.0 & 1052.1 & 1783.7 & 980.5 & 2588.5 & 497.6 \\
\hline Testate amoebae density (ind $\mathrm{L}^{-1}$ ) & 888.0 & 128.0 & 1655.8 & 534.8 & 232.3 & 71.8 & 492.5 & 125.6 \\
\hline Total protozoan density (ind L $\mathrm{L}^{-1}$ ) & 5683.2 & 4016.3 & 7275.1 & 896.2 & 2016.0 & 1219.0 & 2839.0 & 469.2 \\
\hline
\end{tabular}

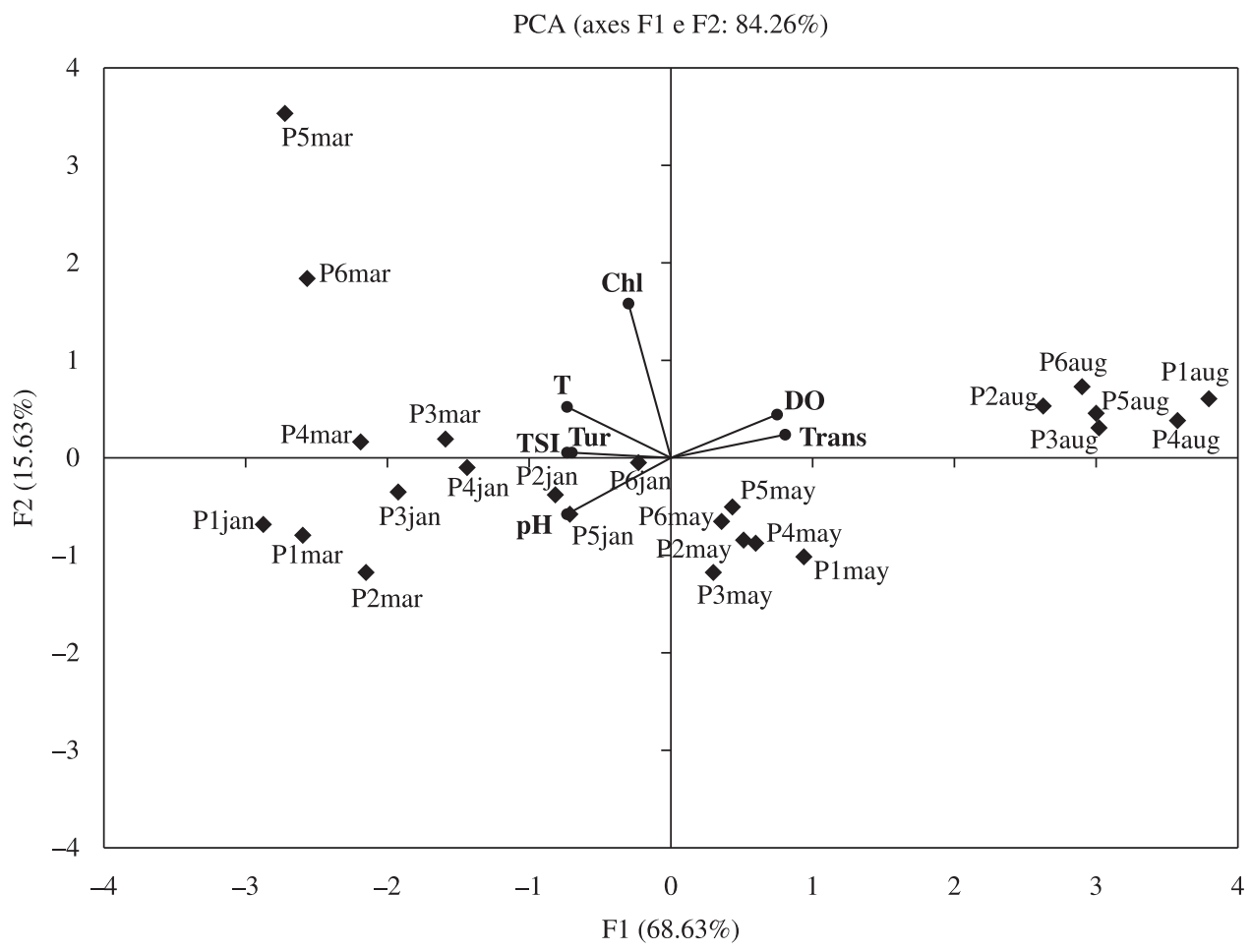

Figure 2. Ordination diagram of PCA with the limnological variables registered in the collection points during the studied period. P1jan to P6jan (Point 1 to Point 6 in January); P1mar to P6mar (Point 1 to Point 6 in March); P1may to P6may (Point 1 to Point 6 in May); P1aug to P6aug (Point 1 to Point 6 in August), DO (dissolved oxygen), Trans (water transparency), Chl (chlorophyll $a$ ), T (temperature), Tur (turbidity), TSI (trophic state index).

August) (see Table 1). The total protozoan density (see Table 3) correlated significantly (positive and negative ones) with all the physical and chemical variables (except for chlorophyll $a$ ). However, the highest positive correlations were with temperature $(\mathrm{r}=0.84, \mathrm{p}<0.05)$ and turbidity $(\mathrm{r}=0.74, \mathrm{p}<0.05)$ and the highest negative correlation was found with water transparency $(\mathrm{r}=-0.76, \mathrm{p}<0.05)$.
The canonical correspondence analysis (CCA) between species and limnological variables (see Figure 4) showed evidence that the sampled points in the dry season tended to stay close in the diagram, indicating that they have a similar protozoan species composition. Among the species, $H$. grandinella was the predominant in all sampled stations (except in the P2D). However, the sampled points in the 
Table 2. Relative proportion (\%) and annual mean density of the taxa identified in Ilha Solteira reservoir during the studied period and their mean values in the rainy and dry seasons. * = observed only in vivo.

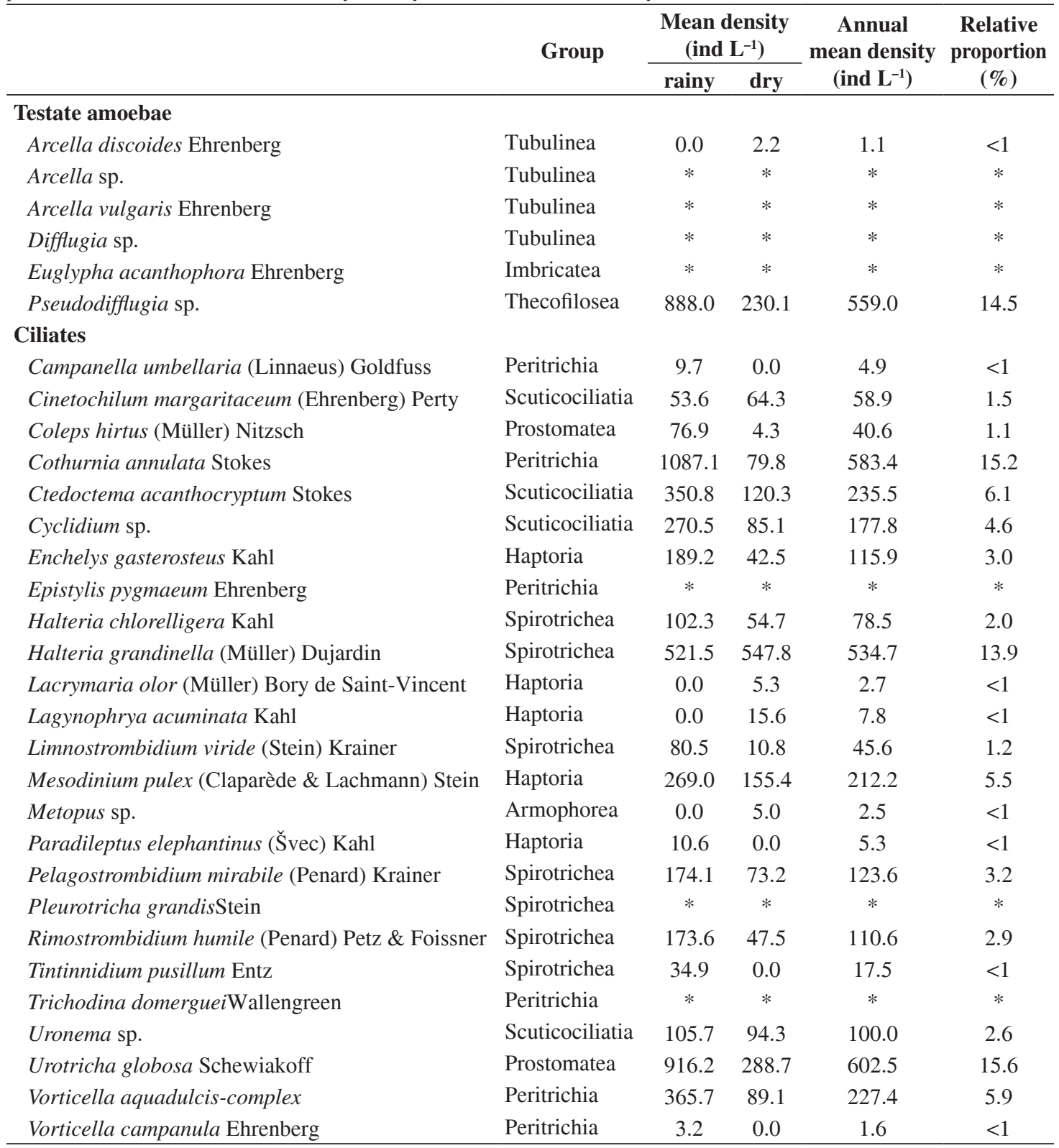

rainy season remained scattered in the diagram, and these were differentiated by limnological variables (mainly turbidity and chlorophyll $a$ ) and species dominance. In point 3 , in the rainy season (P3R) a high density of $C$. annulata was associated to high turbidity. In point 5 , in the rainy season (P5R), a high density of $V$. aquadulcis-complex associated with increased concentrations of chlorophyll $a$ was observed. In the diagram, higher densities of $H$. grandinella were observed in oxygenated environments with high transparency, while for $C$. annulata this occurred in sites with high turbidity, $\mathrm{pH}$ and TSI.
The predominant protozoan groups in the reservoir were Spirotrichea and Peritrichia, followed by Prostomatea, Scuticociliatia and Thecofilosea. Considering the seasonal variations during the studied period, Peritrichia was more important in the rainy season and Spirotrichea in the dry season (see Figure 5).

Table 3 shows the significant Pearson correlations among the variables analyzed in the Ilha Solteira reservoir. Most protozoan groups and species were positively correlated with temperature and turbidity and negatively with water transparency. $H$. grandinella showed a significant positive correlation with the DO $(r=0.46, p<0.05)$ and negative 


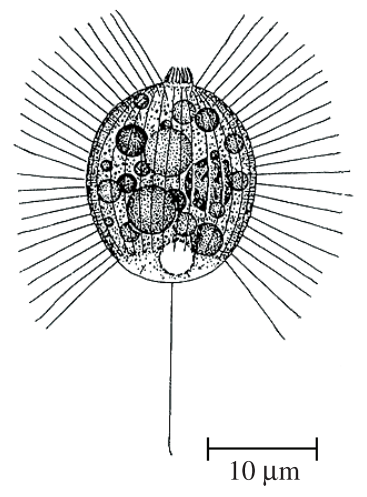

(a)

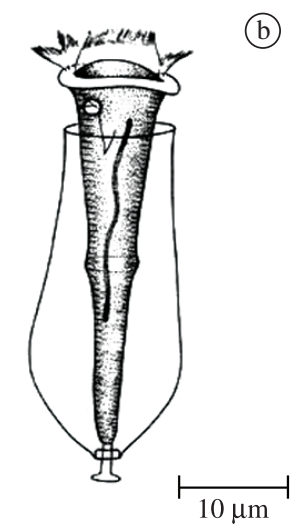

(d)

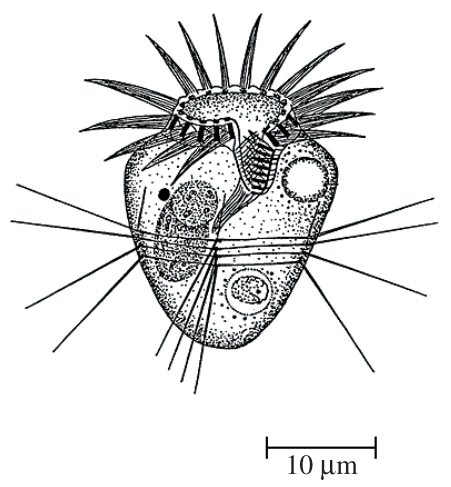

(e)

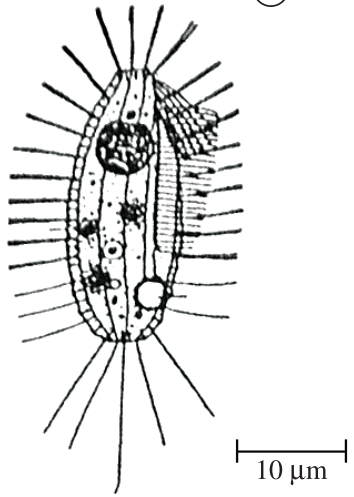

(c)

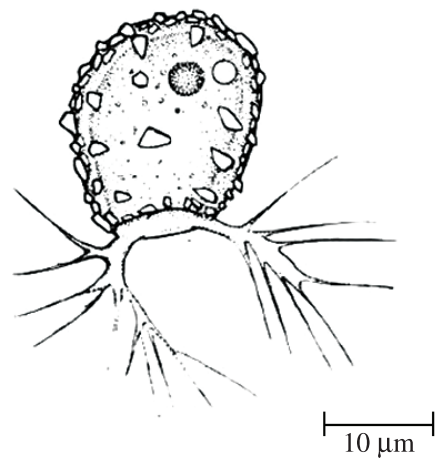

(f)

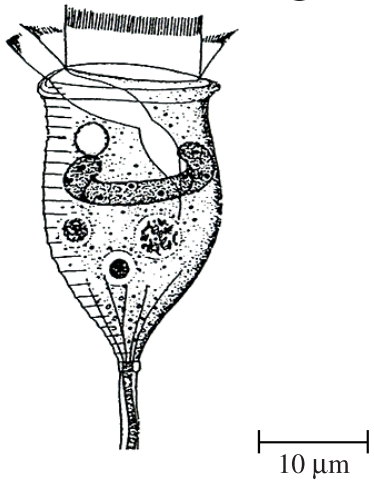

Figure 3. The dominant protozoan in the reservoir Ilha Solteira: a) Urotricha globosa; b) Cothurnia annulata; c) Pseudodifflugia sp.; d) Halteria grandinella; e) Ctedoctema acanthocryptum and f) Vorticella aquadulcis-complex. Figure a, d-f were modified from Foissner et al. (1999) and Figure b, c were modified from Shen and Zhang (1990).

Table 3. Pearson correlation coefficients among the densities of different groups and protozooplanktonic species with other studied variables in Ilha Solteira reservoir. Chl (chlorophyll $a$ ), DO (dissolved oxygen), BOD (biochemical oxygen demand), $\mathrm{T}$ (temperature), Trans (water transparency), Tur (turbidity), TSI (trophic state index), - non significant correlation; $\mathrm{p}<0.05$.

\begin{tabular}{lcccccccc}
\hline \multicolumn{1}{c}{ Variables } & Chl & pH & DO & BOD & T & Trans & Tur & TSI \\
\hline Total protozoan density & - & 0.57 & -0.51 & 0.52 & 0.84 & -0.76 & 0.74 & 0.53 \\
Spirotrichea & - & - & - & 0.46 & - & - & - & - \\
Peritrichia & 0.49 & 0.51 & - & - & 0.66 & -0.65 & 0.68 & 0.58 \\
Prostomatea & - & - & - & - & 0.57 & -0.45 & - & - \\
Scuticociliatia & & 0.66 & -0.52 & 0.45 & 0.60 & -0.68 & 0.75 & 0.61 \\
Thecofilosea & 0.53 & 0.45 & -0.63 & - & 0.75 & -0.59 & 0.54 & 0.54 \\
Haptoria & - & - & - & 0.55 & 0.56 & -0.53 & 0.50 & - \\
Cothurnia annulata & - & 0.48 & - & - & 0.46 & -0.57 & 0.64 & 0.44 \\
Urotricha globosa & - & - & - & - & 0.51 & -0.42 & - & - \\
Pseudodifflugia sp. & 0.53 & 0.45 & -0.63 & - & 0.75 & -0.59 & 0.54 & 0.54 \\
Halteria grandinella & - & - & 0.46 & - & - & - & - & -0.63 \\
Vorticella aquadulcis-complex & 0.92 & - & & - & 0.42 & - & - & - \\
Ctedoctema acanthocryptum & - & 0.57 & -0.54 & - & 0.55 & -0.62 & 0.57 & 0.64 \\
\hline
\end{tabular}


CCA

(axes F1 e F2: 83.69\%)

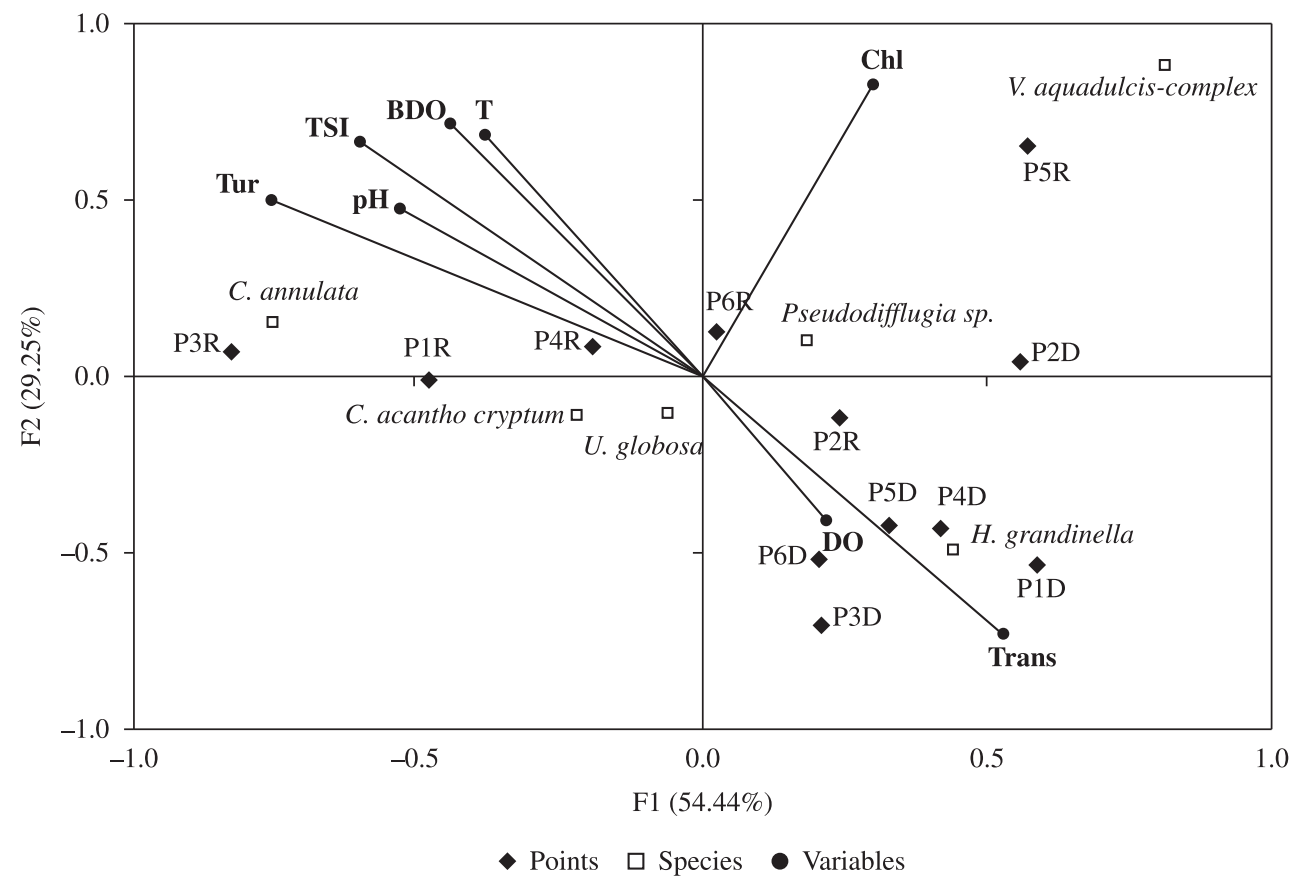

Figure 4. Ordination diagram of CCA with the main species and limnological variables registered during the studied period. P1R to P6R (Point 1 to Point 6 in rainy season); P1D to P6D (Point 1 to Point 6 in dry season), DO (dissolved oxygen), BOD (biochemical oxygen demand), Trans (water transparency); Chl (chlorophyll $a$ ), T (temperature), Tur (turbidity), TSI (trophic state index).

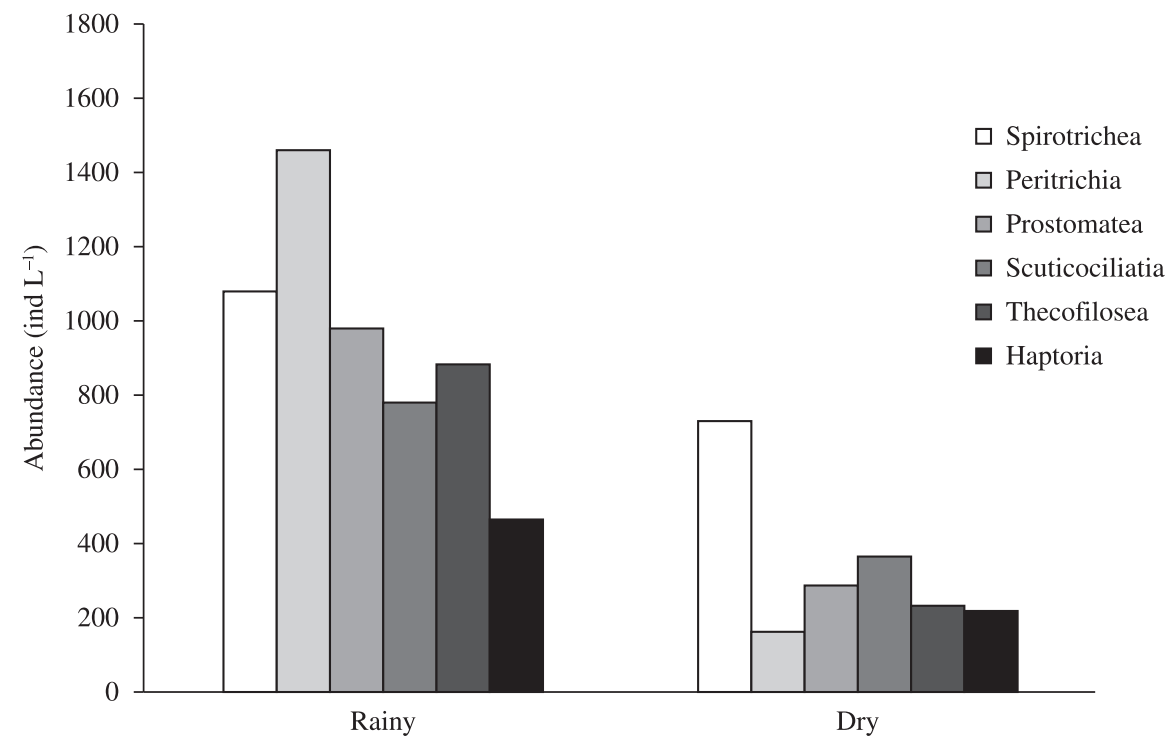

Figure 5. Abundance (ind $\mathrm{L}^{-1}$ ) of the main protozoan groups in the rainy and dry seasons in Ilha Solteira reservoir.

with the TSI $(\mathrm{r}=-0.63, \mathrm{p}<0.05)$ and $V$. aquadulciscomplex correlated positively with chlorophyll $a(\mathrm{r}=0.92$, p < 0.05). C. annulata and Pseudodifflugia sp. correlated positively with turbidity $(\mathrm{r}=0.64$ e $\mathrm{r}=0.54, \mathrm{p}<0.05$, respectively) and negatively with water transparency $(\mathrm{r}=-0.57$ e $\mathrm{r}=-0.59, \mathrm{p}<0.05$, respectively $)$. 


\section{Discussion}

Statistical analysis (PCA and Student's t-tests) of the studied variables (mainly temperature, dissolved oxygen, turbidity and water transparency) confirmed, for the studied period, the climatological pattern typical of the region (rainy/warm and dry/cold). During the year, precipitation in the summer probably produced inputs of nutrients and suspended solids in the system and the winds in the winter increased water turbulence, causing an enhancement of dissolved oxygen (DO) concentration and homogenization of the water column. Moreover, the concentration of DO in the winter is probably also related to the higher solubility of oxygen as a consequence of the lower water temperatures.

The protozooplankton community showed seasonal variations with higher densities and species diversity in the rainy season in comparison with the dry season. In other Brazilian reservoirs from tropical and subtropical regions, which have the same regime of dry and rainfall, similar protozoan seasonality patterns were found (e.g. Gomes and Godinho, 2003; Araújo and Costa, 2007). These higher values in the rainy season were probably due to the precipitation that may have caused: 1) sediment resuspension carrying some benthic protozoans to the water column; 2) the entrance of soil protozoa coming from the drainage basin along with protozoans originated from rivers whose water volume increases at this season. Protozoan density could also be affected by temperature, a fact confirmed by the high positive correlation between these variables. The increasing protozoan density with temperature could be related to the enhancement of their: 1) reproductive rates due to the higher metabolic rates; and 2) prey and predator populations that normally are also positively affected by temperature. However, neither the prey, nor the predator populations were evaluated in this study.

The mean protozoan density obtained in the reservoir, whose trophic state index pointed to the oligotrophic, was low compared to eutrophic environments (e.g. Velho et al., 2005; Araújo and Costa, 2007; Chróst et al., 2009; Kiss et al., 2009; Xu and Cronberg, 2010) and within the range of those found in other oligotrophic systems (e.g. Quevedo et al., 2003; Pirlot et al., 2005; Macek et al., 2006; De Wever et al., 2007; Claessens et al., 2010). This pattern is expected because, according to Laybourn-Parry (1992), the protozoan densities increase with the trophic level of the ecosystems.

Concerning the dominant protozoan in the system, organisms such as Halteria grandinella, Urotricha sp. and Vorticella spp. are frequently reported in Brazilian aquatic environments (e.g. Barbieri and Godinho, 1989; Pauleto et al., 2009), and have widespread geographic distribution (Foissner et al., 1999; Šimek et al., 2000). One of the reasons for the prevalence of U. globosa and $H$. grandinella might be the jumping ability of these species which is an effective strategy for escaping from predation by cladocerans and rotifers (Gilbert, 1994). The H. grandinella also has a broad diet (bacteria, autotrophic and heterotrophic nanoprotists, detritus), which can be a selective advantage compared with specialized bacterivorous or algivores ciliates, resulting usually in a numerical dominance of this species in freshwater plankton (Jürgens and Šimek, 2000). The dominance of the Vorticella may also be due to its ability to escape predators due to the myonema contraction in the peduncle.

Interestingly, the higher densities of $V$. aquadulciscomplex were associated to the increase of phytoplankton (high positive correlation between this species and chlorophyll a) in the rainy season (mainly in March). A concomitant density increase of this species and Microcystis spp. was also observed, which usually remains suspended in the water column, and it is used as a fixation substract by this protozoan. The association between these two species has been frequently reported in the literature (e.g. Pratt and Rosen, 1983).

Among the prevalent protozoans in the system, $C$. annulata was especially important during the rainy season, probably due to a higher amount of suspended particles (positive correlation with turbidity) when compared to the dry season (negative correlation with the water transparency). Since this is a sessile species, the suspended material should be important for use as a fixation substrate.

Pseudodifflugia sp. was the most important testate amoebae in the system, having the highest densities during the rainy season, when the reservoir showed a high turbidity and high amount of suspended solids (observed by the low value of water transparency). Probably such predominance in this period was due to the influence of the sediment in the water column, because it is known that the sediment is one of the places of origin of these organisms (Lansac-Tôha et al., 2000).

Considering the protozoan trophic function in the reservoir, the numerical predominance of the bacterivorous/ algivores protozoan types was noted. The dominance of this type of feeding can be explained by the easiness of the adaptation to fluctuations on food availability, a desirable characteristic for the organisms, especially in oligotrophic environments such as this. The most common protozoans in the system with this feeding preference were Spirotrichea and Prostomatea ciliates, which also have small dimensions that determine rapid growth rates.

In Ilha Solteira reservoir, the Spirotrichea, Prostomatea and Scuticociliatia were the dominant ciliate groups which are made up of small sized organisms. The dominance of small protozoan species is not the usual for oligotrophic waters. Studies have shown the dominance of small protozoan species $(<30 \mu \mathrm{m})$, mainly oligotrichs (Spirotrichea) and prostomatids (Prostomatea) in mesotrophic and eutrophic temperate lakes (e.g. Macek et al., 1996), while species from Scuticociliatia, Haptoria and Peritrichia are usually less numerous (Šimek et al., 2000). On the other side, according to Beaver and Crisman (1989) and Modenutti and Pérez (2001) the Oligotrichida (Spirotrichea) dominate numerically in oligotrophic lakes, while Scuticociliatia and Haptoria predominate in environments with higher trophic level (Beaver and Crisman, 1989).

Seasonally in the reservoir, Peritrichia was more important in the rainy season and Spirotrichea in the dry season. This pattern reflects the effect of precipitation in determining the protozooplankton composition of the environment. During the dry season the protozoans groups that are truly planktonic, such as oligotrichs (Spirotrichea), were predominant, whereas in the rainy season a greater input of allochthonous particulate and biological material 
by the rivers probably occurred, as well as the sediment resuspension (verified by the high turbidity and low water transparency), which enriched the local biota with the entry of protozoan that tend to live on particulate surfaces, such as sessile protozoans from the Peritrichia group.

When the Pearson correlation was applied to total protozoan densities and chlorophyll, the result was not significant, whereas the chlorophyll concentration was low throughout the year (mean $1.6 \mathrm{mg} \mathrm{L}^{-1}$ ) and showed small fluctuations (except for P5 and P6 in March). This fact was already expected because in nutrient-poor environments, such as oligotrophic ones, the abundance of the phytoplankton community is generally low and reveals small seasonal variations. According to Sanders et al. (1992), the bottom-up control is more important in oligotrophic systems, while the top-down control is more important in eutrophic environments. Thus, as the studied reservoir is poor in nutrients and algae (low chlorophyll concentration) probably the protozoan community was controlled by resources (bottom-up control). However, this does not imply that in all the months of the year, the control in the reservoir was by resources, and that this is the main control for all the protozoan groups, due to the diversity of feeding strategies and predation escape of themselves.

The results of this work showed evidence of the importance of limnological studies with protozoan, as well as the analysis of the results considering the species or at least the taxonomic and/or functional groups. Due to the great diversity of species and life strategies, especially nutritive and to avoid predation, the roles of protozoan in the systems are multiple. When an analysis of protozoan is made regarding them as a single and homogeneous group, the interpretations of their importance in the studied environment might be totally distorted. The study demonstrated that the protozooplankton community of the Ilha Solteira reservoir experienced seasonal variation in relation to the density and composition of species and groups due to the environmental variables, mainly temperature, turbidity and water transparency related to the influence of the rainfall, DO and TSI. Moreover, biological variables, such as morphological characteristics (small cell, mostly $<30 \mu \mathrm{m}$ ), places of origin (Pseudodifflugia sp. resuspended from sediment), eating habits (broad diet of $H$. grandinella) and strategies of escaping from predators (jumping ability of $U$. globosa and $H$. grandinella) of the species, also influenced seasonal variation of this community. However, more studies must be conducted about the patterns and responses of the protozooplankton to the seasonal variations of environmental and biotic conditions, looking for relationships that contribute to the understanding of the protozoan ecology in aquatic systems of different trophic levels and climates to which they are exposed to.

Acknowledgements - We would like to thank Mrs. Darci D. Javaroti for the laboratory assistance and FAPESP (process $n^{\circ}$ 06/57209-5) for the scholarship granted to the first author.

\section{References}

American Public Health Association - APHA, 1995. Standard methods for examination of water and wasterwater. 19th ed. Washington: APHA.
ARAÚJO, MFF. and COSTA, IAS., 2007. Comunidades microbianas (bacterioplâncton e protozooplâncton) em reservatórios do semiárido brasileiro. Oecologia brasiliensis, vol. 11, p. 422-432.

AZAM, F., FENCHEL, T., FIELD, JG., GRAY, JS., MEYERREIL, LA. and THINGSTAD, F., 1983. The ecological role of water-column microbes in the sea. Marine Ecology Progress Series, vol. 10, p. 257-263. http://dx.doi.org/10.3354/meps010257

BARBIERI, SM. and GODINHO, MJL., 1989. Ecological studies on the planktonic protozoa of a eutrophic reservoir (Rio Grande Reservoir - Brazil). Hydrobiologia, vol. 183, p. 1-10. http://dx.doi. org/10.1007/BF00005966

BEAVER, JR. and CRISMAN, TL., 1989. The role of ciliated protozoa in pelagic freshwater ecosystems. Microbial Ecology, vol. 17, p. 111-136.

,- 1990 . Seasonality of planktonic ciliated protozoa in 20 subtropical Florida lakes of varying trophic state. Hydrobiologia, vol. 190, p. 127-135. http://dx.doi.org/10.1007/BF00014103

BELL, T., BONSALL, MB., BUCKLING, A., WHITELEY, AS., GOODALL, T. and GRIFFITHS, RI., 2010. Protists have divergent effects on bacterial diversity along a productivity gradient. Biology Letters, vol. 6, p. 639-642. PMid:20219744 PMCid:2936128. http://dx.doi.org/10.1098/rsbl.2010.0027

BRANDS, SJ. (Comp.), 1989-2005. Systema Naturae 2000. Amsterdam, The Netherlands. Available from: http://sn2000. taxonomy.nl/>. Access in: 20 May 2011.

CARLSON, RE., 1977. A trophic state index for lakes. Limnology and Oceanography, vol. 22, p. 261-269.

CHRÓST, RJ., TOMASZ, A., KALINOWSKA, K. and SKOWRONSKA, A., 2009. Abundance and Structure of Microbial Loop Components (Bacteria and Protists) in Lakes of Different Trophic Status. Journal of Microbiology and Biotechnology, v. 19, p. 858-868. PMid:19809240. http://dx.doi.org/10.4014/ jmb.0812.651

CLAESSENS, M., WICKHAM, SA., POST, AF. and REUTER, M., 2010. A paradox of the ciliates? High ciliate diversity in a resource-poor environment. Marine Biology, vol. 157, p. 483-494. http://dx.doi.org/10.1007/s00227-009-1334-7

CORNO, G., CARAVATI, E., CALLIERI, C. and BERTONI, R., 2008. Effects of predation pressure on bacterial abundance, diversity, and size-structure distribution in an oligotrophic system. Journal of Limnology, vol. 67, p. 107-119. http://dx.doi. org/10.4081/jlimnol.2008.107

DE WEVER, A., MUYLAERT, K., COCQUYT, C., VAN WICHELEN, J., PLISNIER, PD. and VYVERMAN, W., 2007. Seasonal and spatial variability in the abundance of auto - and heterotrophic plankton in Lake Tanganyika, Fundamental and Applied Limnology, vol. 170, p. 49-63. http://dx.doi.org/10.1127/18639135/2007/0170-0049

EDMONDSON, WT., 1959. Freshwater Biology. New York: John Wiley and Sons. 1248 p.

FOISSNER, W., 1988. Taxonomic and nomenclatural revision of Sládecek's list of ciliates (Protozoa: Ciliophora) as indicators of water quality. Hydrobiologia, vol. 166, p. 1-64. http://dx.doi. org/10.1007/BF00017483

FOISSNER, W. and BERGER, H., 1996. A user-friendly guide to the ciliates (Protozoa, Ciliophora) commonly used by hydrobiologists as bioindicators in rivers, lakes and waste waters, with notes on their ecology. Freshwater Biology, vol. 35, p. 375-482.

FOISSNER, W., BERGER, H. and SCHAUMBURG, J., 1999. Identification and ecology of limnetic plankton ciliates. 
Munich: Informationsberichte des Bayer Landesamtes für Wasserwirtschaft. 793 p.

GILBERT, JJ., 1994. Jumping behavior in the oligotrich ciliates Strobilidium velox and Halteria grandinella and its significance as a defense against rotifer predators. Microbial Ecology, vol. 27, p. 189-200. http://dx.doi.org/10.1007/BF00165817

GOLTERMAN, HL., CLYMO, RS. and OHNSTAD, MAM., 1978. Methods for physical and chemical analysis of freshwaters. London: International Biological Programme. 213 p.

GOMES, EAT. and GODINHO, MJL., 2003. Structure of the protozooplankton community in a tropical shallow and eutrophic lake in Brazil. Acta Oecologica, vol. 24, p. 153-161. http://dx.doi. org/10.1016/S1146-609X(03)00039-0

JÜRGENS, K. and ŠIMEK, K., 2000. Functional response and particle size selection of Halteria cf. grandinella, a common freshwater oligotrichous ciliate. Aquatic Microbial Ecology, vol. 22, p. 57-68. http://dx.doi.org/10.3354/ame022057

KISS, AK., ACS, E., KISS, KT. and TOROK, JK., 2009. Structure and seasonal dynamics of the protozoan community (heterotrophic flagellates, ciliates, amoeboid protozoa) in the plankton of a large river (River Danube, Hungary). European Journal of Protistology, vol. 45, p. 121-138. PMid:19285382. http://dx.doi.org/10.1016/j. ejop.2008.08.002

LANSAC-TÔHA, FA., VELHO, LFM., ZIMMERMANNCALLEGARI, MC., BONECKER, CC., 2000. On the occurrence of testate amoebae (Protozoa, Rhizopoda) in Brazilian inland waters. I. Family Arcellidae. Acta Scientiarum, vol. 22, no. 2, p. 355-363.

LAYBOURN-PARRY, J., 1992. Protozoan Plankton Ecology. London: Chapman and Hall. 231p.

LAYBOURN-PARRY, J. and WALTON, M., 1998. Seasonal heterotrophic flagellate and bacterial plankton dynamics in a large oligotrophic lake - Loch Ness, Scotland. Freshwater Biology, vol. 39, p. 1-8. http://dx.doi.org/10.1046/j.1365-2427.1998.00253.x

LEE, JJ., HUTNER, SH. and BOVEE, EC., 1985. An illustrated Guide to the Protozoa. Lawrence, Kansas: Society of Protozoologists.

LYNN, DH., 2008. The ciliated Protozoa: characterization, classification, and guide to the literature. 3rd ed. Springer. $605 \mathrm{p}$.

MACEK, M., CALLIERI, C., ŠIMEK, K. and VÁZQUEZ, AL. 2006. Seasonal dynamics, composition and feeding patterns of ciliate assemblages in oligotrophic lakes covering a wide $\mathrm{pH}$ range. Archiv Fur Hydrobiologie, vol. 166, p. 261-287. http:// dx.doi.org/10.1127/0003-9136/2006/0166-0261

MACEK, M., ŠIMEK, K., PERNTHALER, J., VYHNÁLEK, V. and PSENNER, R., 1996. Growth rates of dominant planktonic ciliates in two freshwater bodies of different trophic degree. Journal of Plankton Research, vol. 18, p. 463-481. http://dx.doi. org/10.1093/plankt/18.4.463

MODENUTTI, BE. and PÉREZ, GL., 2001. Planktonic ciliates from an oligotrophic south Andean lake, Morenito lake (Patagonia, Argentina). Brazilian Journal of Biology, vol. 61, p. 389-395. PMid:11706565.

NUSCH, EA., 1980. Comparasion of diferent methods for Clorophyll-a and phaeopigments determination. Archiv für Hydrobiologie, vol. 14, p. 14-36.

PACE, ML. and ORCUTT, JD., 1981. The relative importance of protozoans, rotifers and crustaceans in a freshwater zooplankton community. Limnology and Oceanography, vol. 36, p. 822-830.

PAERL, HW., DYBLE, J., MOISANDER, PH., NOOBLE, RT., PIEHLER, MF., PINCKNEY, JL., STEPPE, TF., TWOMEY, L. and VALDES, LM., 2003. Microbial indicators of aquatic ecosystem change: current applications to eutrophication studies. FEMS Microbiology Ecology, vol. 46, p. 233-246. http://dx.doi. org/10.1016/S0168-6496(03)00200-9

PAULETO, GM., VELHO, LFM., BUOSI, PRB., BRÃO, AFS., LANSAC-TÔHA, FA. and BONECKER, CC., 2009. Spatial and temporal patterns of ciliate species composition (Protozoa: Ciliophora) in the plankton of the Upper Paraná River floodplain. Brazilian Journal of Biology, vol. 69, no. 2 Supplement, p. 517-527. PMid:19738959. http://dx.doi.org/10.1590/S151969842009000300007

PERNTHALER, J., 2005. Predation on prokaryotes in the water column and its ecological implications. Nature, vol. 3, p. 537-546.

PIRLOT, S., VANDERHEYDEN, J., DESCY, JP. and SERVAIS, P., 2005. Abundance and biomass of heterotrophic microorganisms in Lake Tanganyika. Freshwater Biology, vol. 50, p. 1219-1232. http://dx.doi.org/10.1111/j.1365-2427.2005.01395.x

PRATT, JR. and ROSEN, BH., 1983. Association of Vorticella (Peritrichida) and Planktonic Algae. Transactions of the American Microscopical Society, vol. 102, p. 48-54. http:// dx.doi.org/10.2307/3225924

QUEVEDO, M., VIESCA, L., ANADÓN, R. and FERNÁNDEZ, E., 2003. The protistan microzooplankton community in the oligotrophic north-eastern Atlantic: large- and mesoscale patterns. Journal of Plankton Research, vol. 25, p. 551-563. http://dx.doi. org/10.1093/plankt/25.5.551

SANDERS, RW., CARON, DA. and BERNINGER, UG., 1992. Relationships between bacteria and heterotrophic nanoplankton in marine and fresh waters: an inter-ecosystem comparison. Marine Ecology Progress Series, vol. 86, p. 1-14. http://dx.doi. org/10.3354/meps086001

SHEN, YF. and ZHANG, Z., 1990. Modern Biomonitoring Techniques Using Freshwater Microbiota. Beijing: China Architecture and Building Press. [in Chinese; illustrations available online at micro*scope: http://starcentral.mbl.edu/microscope/portal.php? pagetitle $=$ collectiondetails \& collectionID $=106]$.

ŠIMEK, K., JÜRGENS, K., NEDOMA, J., COMERMA, M. and ARMENGOL, J., 2000. Ecological role and bacterial grazing of Halteria spp.: small freshwater oligotrichs as dominant pelagic ciliate bacterivores. Aquatic Microbial Ecology, vol. 22, p. 43-56. http://dx.doi.org/10.3354/ame022043

TOLEDO, APJR., TALARICO, M., CHINEZ, SJ. and AGUDO, EG., 1983. A aplicação de modelos simplificados para avaliação do processo da eutrofização em lagos e reservatórios tropicais. In Congresso Brasileiro de Engenharia Sanitária e Ambiental, 1983. São Paulo: Cetesb. p. 1-34.

TREMAINE, SC. and MILLS, AL., 1991. Impacto of Water Column Acidification on Protozoan Bacterivory at the Lake Sediment-Water Interface. Applied and Environmental Microbiology, vol. 57, p. 775-784. PMid:16348443 PMCid:182794.

VALDERRAMA, JC., 1981. The simultaneous analysis of total nitrogen and phosphorus in natural waters. Marine Chemistry, vol. 10, p. 1109-122.

VELHO, LFM., PEREIRA, DG., PAGIORO, TA., SANTOS, VD., PERENHA, MCZ. and LANSAC-TÔHA, FA., 2005. Abundance, biomass and size structure of planktonic ciliates in reservois with distinct trophic states. Acta Limnologica Brasiliensia, vol. 17 , p. 361-371.

XU, R. and CRONBERG, G., 2010. Planktonic ciliated protozoan in western basin of Lake Ringsjön, Sweden: community structure, seasonal dynamics and long-term changes. Protistology, vol. 6, no. 3 , p. 173-187. 